\title{
PENERAPAN DESAIN PRAKTIKUM BERBASIS STEM PADA PEMBUATAN TEMPE DARI FERMENTASI BIJI NANGKA (ARTOCARPUS HETEROPHYLLUS) UNTUK MENINGKATKAN LITERASI SAINS SISWA SMK
}

\author{
R. A. Amahoroe ${ }^{1^{*}}$, M. Arifin ${ }^{2}$, H. Solihin ${ }^{2}$ \\ ${ }^{1}$ Pendidikan Kimia, Universitas Pattimura Ambon \\ ${ }_{2}^{2}$ Pendidikan Kimia, Universitas Pendidikan Indonesia
}

*raamahoroe@gmail.com

\begin{abstract}
ABSTRAK
Penelitian ini bertujuan untuk menghasilkan desain praktikum berbasis STEM fermentasi tempe dari biji nangka pada pembelajaran fermentasi. Metode penelitiannya adalah $R \& D$ dengan tipe ADDIE dan desain penelitian One Group Pretest-Postest. Subjek penelitian terdiri dari 25 siswa Kelas X di Cisarua. Instrumen yang digunakan antara lain: LKS, lembar observasi keterlaksaan RPP, tes peningkatan literasi sains. Hasil penelitian menunjukkan bahwa karakteristik desain praktikum berbasis STEM antara lain: memecahkan permasalahan yang ada dalam kehidupan sehari-hari, mengintegrasikan STEM dalam praktikum yang berbasis proyek, serta meningkatan kemampuan 4C dan literasi sains siswa. Penerapan desain praktikum berbasis STEM pada pembelajaran fermentasi dapat terlaksana dengan sangat baik dengan keterlaksanaan pembelajaran pada Pertemuan I untuk guru dan siswa, sebesar 95\% dan 92,58. Pertemuan II sebesar 93,89\% dan $93,36 \%$ serta Pertemuan III sebesar $100 \%$ dan $92,26 \%$. Selanjutnya hasil belajar siswa menunjukkan peningkatan literasi sains siswa setelah praktikum berbasis STEM diterapkan dengan rata-rata nilai $\mathrm{N}$-Gain adalah sebesar 0,76 . Sedangkan indikator literasi sains siswa mengalami peningkatan paling tinggi adalah aspek menafsirkan data dan bukti ilmiah dan yang paling rendah adalah menggunakan konsep, fakta, prosedur, dan penalaran. Hal ini berarti penggunaan LKS praktikum berbasis STEM dapat meningkatkan kemampuan literasi sains siswa SMK.
\end{abstract}

Kata Kunci: Desain praktikum, STEM, Literasi sains, Fermentasi.

\section{PENDAHULUAN}

Masyarakat di Abad 21 dihadapkan dengan berkembangnya revolusi industri 4.0 yang mewajibkan siswa untuk menguasi keterampilan 4C, komunikasi (Communication), kolaborasi (Collaboration), berpikir kritis (Critical thinking) dan memecahkan masalah (Problem solving), serta kreativitas (Creativity) dan inovasi (Innovation) (Greenstein, 2012). Untuk itu, pendidikan sains berperan penting untuk menyiapkan siswa yang memiliki literasi sains. Siswa yang berliterasi sains adalah siswa yang mampu untuk berpikir kritis, kreatif, logis, dan berinisiatif dalam menanggapi isu di masyarakat yang diakibatkan dampak perkembangan sains dan teknologi atau dengan kata lain siswa yang berliterasi sains adalah siswa yang memiliki keterampilan 4C yang dibutuhkan di Abad 21 (Nofiani dkk., 2018; Windyariani, 2017; Ismail dkk., 2016).

Grabe menggambarkan literasi sains sebagai hasil persinggungan antara "what do people know" (terdiri atas kompetensi sains dan kompetensi epistemologis), "what do people value" (terdiri atas kompetensi etika/moral), dan "what can people do" (terdiri dari kompetensi belajar, kompetensi sosial, kompetensi prosedural, dan kompetensi berkomunikasi). Artinya, orang yang berliterasi sains tidak hanya mumpuni dalam konten dan proses serta keterampilan sains, melainkan juga memiliki sikap dan etika/moral (Holbrook dkk., 2009). Komponen-komponen dalam model literasi sains Graber ini sesuai dengan kompetensi-kompetensi inti dalam Kurikulum 2013. Apabila kompetensi inti dalam Kurikulum 2013 dipetakan dalam model literasi sains Graber, maka KI 1 dan $\mathrm{KI} 2$ masuk dalam komponen "what people value", KI 3 masuk dalam komponen "what people know", dan KI 4 masuk dalam komponen "what people do". Artinya, semua kompetensi inti kurikulum 2013 masuk dalam kategori literasi sains Graber. 
Uraian di atas menunjukkan pentingnya literasi sains bagi siswa, sebagai tuntutan kurikulum 2013 sekaligus tuntutan di Abad 21. Akan tetapi, berdasarkan hasil salah satu studi internasional yang mengukur tingkat pencapaian kemampuan sains siswa yaitu Trends in International Mathematics Science Study (TIMSS) 2011, posisi Indonesia menempati peringkat ke-40 dari 42 negara dengan nilai rata-rata 406. Informasi penilaian TIMSS tersebut menunjukkan kemampuan sains siswa Indonesia mengalami penurunan prestasi. Kemampuan sains siswa Indonesia di TIMSS masih di bawah nilai rata-rata (500) dan secara umum berada pada tahapan terendah (Low International Brenchmark) (Kemdikbud, 2013). Rendahnya mutu hasil belajar sains siswa tersebut menunjukkan bahwa proses pembelajaran sains di sekolah-sekolah Indonesia telah mengabaikan perolehan kepemilikan literasi sains siswa.

Pada survey Programme for International Student Assessment (PISA) tahun 2012, dari total 65 negara dan wilayah yang masuk survei PISA, Indonesia menduduki ranking ke-64. Hasil penelitian tentang profil literasi sains siswa di salah satu kota di Indonesia juga menunjukkan bahwa literasi sains siswa dalam aspek konten, konteks, maupun proses masih tergolong rendah (Nofiana, 2017). Selanjutnya, hasil penelitian Bagasta dkk., (2018), menunjukkan bahwa kemampuan literasi sains siswa berdasarkan indikator, yaitu identifikasi pendapat ilmiah sebesar, memahami elemen desain penelitian, memecahkan masalah sebesar, serta menarik kesimpulan masih sangat rendah. Oleh karena itu diperlukan proses pembelajaran yang dapat meningkatkan literasi sains siswa. Salah satu pembelajaran yang dapat meningkatkan literasi sains siswa adalah pembelajaran praktikum.

Pembelajaran praktikum dapat meningkatkan pencapaian literasi sains sebab pembelajaran praktikum tidak hanya sekedar menekankan pada hafalan pengetahuan saja, melainkan berorientasi pada proses dan ketercapaian sikap ilmiah. Selain itu pembelajaran dengan praktikum juga membantu siswa untuk berlatih memahami suatu fenomena ilmiah dengan melakukan sendiri observasi, eksperimen serta kegiatan empiris maupun analitis (Sudargo dkk., 2009). Cimer (2007) juga berpendapat bawah praktikum membuat siswa mampu mengkontruksi pengetahuan mereka sendiri. Oleh karena itu praktikum dapat meningkatkan kemampuan literasi sains siswa (Rakhmawan dkk., 2015; Jaka dkk., 2016). Hal ini juga sejalan dengan hasil penelitian Azizah dkk., (2015), yang menunjukkan bahwa pembelajaran praktikum dapat menumbuhkan kemampuan berpikir, bekerja dan bersikap ilmiah serta mengkomunikasikannya sebagai aspek penting kecakapan hidup. Pemberian pengalaman langsung dalam praktikum diharapkan dapat membantu siswa untuk memperoleh pemahaman yang lebih mendalam tentang alam sekitar. Sedangkan, keaktifan dalam mengikuti proses praktikum diperlukan agar pengetahuan yang diperoleh siswa dapat lebih bertahan lama.

Praktikum dilaksanakan dalam kerja kolaboratif sehingga siswa akan mampu berkolaborasi sekaligus akan terampil berkomunikasi. Selain itu kebermaknaan dalam praktikum juga dapat dicapai dengan cara mengaitkan konsep yang dipelajari siswa dengan kehidupan sehari-hari, hal ini dikarenakan keberhasilan pembelajaran dalam mewujudkan visinya ditunjukkan apabila siswa memahami apa yang dipelajari (Hofstein, 2013). Selain dengan metode praktikum, untuk membentuk individu yang memiliki literasi sains sangat erat hubungannya dengan sains, teknologi, rekayasa, dan matematika. Produk teknologi dihasilkan berdasarkan sains, yang umumnya selalu dijembatani oleh matematika, yaitu kapasitas seorang individu untuk mengidentifikasi dan memahami peranan yang dimainkan matematika terhadap dunia, untuk mengokohkan penilaian, dan mengikat matematika dengan cara yang sesuai dengan kebutuhan individu saat ini dan untuk kehidupan pada masa yang akan datang sebagai warga negara yang konstruktif, peduli, dan reflektif. Oleh karena itu pengintegrasian science, technology, engineering, dan mathematics (STEM) dalam praktikum dapat meningkatkan literasi sains siswa (Permanasari, 2016).

Metode praktikum dengan pendekatan STEM dapat membentuk siswa yang mampu untuk memecahkan masalah dalam kehidupan nyata, membuat pembaruan (innovation), menemukan/merancang hal baru, memahami diri, melakukan pemikiran logis dan menguasai teknologi. STEM merupakan pendekatan pembelajaran yang menghubungkan empat bidang yaitu science, technology, engineering, dan mathematics (STEM) menjadi satu kesatuan yang holistik (Roberts, 2012). Tujuan STEM dalam dunia pendidikan sejalan dengan tuntutan pendidikan abad 21, yaitu agar siswa sains, serta mampu mengembangkan kompetensi yang telah dimilikinya untuk 
diterapkan dalam menghadapi permasalahan dalam kehidupan sehari-hari yang terkait bidang ilmu STEM (Bybee, 2013).

Penggunaan pendekatan STEM dalam pembelajaran dapat membantu siswa dalam menerapkan serta mempraktikan STEM dalam kehidupan sehari-hari sehingga siswa dapat menjadi individu yang berliterasi sains. Praktikum dengan pendekatan STEM mengarahkan siswa untuk mengidentifikasi, mengintegrasikan, mengaplikasikan konsep STEM untuk memahami kemudian menyelesaikan permasalahan yang kompleks (Balka, 2011).

Hasil dari beberapa penelitian yang membuktikan bahwa pengintegrasi STEM dalam pembelajaran dapat menciptakan pembelajaran bermakna, dan membangun sikap positif siswa (Tseng, 2013); membangun keterampilan berpikir kritis siswa dalam memecahkan masalah serta membangun komunikasi dan hubungan kolaboratif antar siswa yang beragam (Capraro \& Jones, 2013). Lebih lanjut penelitian Afriana, dkk. (2015), Khaeroningtyas (2016) menyimpulkan bahwa integrasi pendekatan STEM dalam pembelajaran dapat meningkatkan literasi sains. Hasil penelitian Firman (2018), juga menunjukkan bahwa pengintegrasian STEM dalam pembelajaran dapat menjadi salah satu alternatif pembelajaram untuk mewujudkan pendidikan kimia era industry 4.0.

Salah satu materi sains yang dapat disampaikan dengan praktikum dengan menggunakan pendekatan STEM adalah materi fermentasi. Fermentasi merupakan salah satu materi yang terdapat pada kurikulum SMK yang diajarkan pada mata pelajaran mikrobiologi yang dalam proses pembelajarannya dapat mengintegrasikan STEM dalam proses pembelajarannya. Adanya intergrasi sains dan matematika yang diikuti dengan berkembangnya teknologi dan rekayasa dalam bidang industri dapat menghasilkan banyak produk makanan dan minuman fermentasi untuk menunjang kualitas hidup masyarakat. Siswa mengenal dan mengonsumsi berbagai produk pangan hasil fermentasi, namun umumnya siswa tidak mengetahui bahwa sebetulnya produk pangan yang mereka konsumsi merupakan hasil dari proses fermentasi.

Proses fermentasi dalam penelitian ini akan menghasilkan tempe dari fermentasi biji nangka. Seperti yang kita ketahui bahwa di Indonesia tanaman nangka dapat tumbuh hampir disetiap daerah, akan tetapi masyarakat belum tahu bagaimana cara mengolah dan memanfaatkan biji nangka secara maksimal untuk memenuhi kebutuhan sehari-hari. Masyarakat pada umumnya belum tahu kandungan gizi dari biji nangka yang sering mereka buang sehingga menjadi sampah. Dalam biji nangka terdapat kandungan gizi diantaranya; protein, karbohidrat, lemak, dan lain-lain yang dapat menggantikan kedelai sebagai bahan baku pembuatan tempe (Hayati, 2009). Praktikum pembuatan tempe dari fermentasi biji nangka dapat menjadi edukasi kepada siswa-siswa sehingga mereka juga mampu mengedukasi masyarakat dalam lingkungan mereka tinggal untuk mengolah biji nangka menjadi makanan yang bergizi. Tempe dari fermentasi biji nangka bisa menjadi solusi kurangnya pasokan kedelai sebagai bahan baku pembuatan tempe, serta masyarkat tidak lagi menjadikan biji nangka menjadi sampah yang tidak berguna.

Berdasarkan latar belakang yang telah peneliti sampaikan diatas, maka peneliti mencoba untuk mendesain praktikum pembuatan tempe dari fermentasi biji nangka dengan pendekatan STEM yang dituangkan didalam komponen perangkat pembelajaran berupa lembar kegiatan siswa (LKS). Kemudian diterapkan dalam pembelajaran untuk meningkatkan literasi sains siswa. Desain praktikum dengan pendekatan STEM menginkorporasi konten sains, teknologi, rekayasa dan matematika dalam proses fermentasi.

\section{METODE PENELITIAN}

Penelitian ini menggunakan metode Research and Development (R\&D) dengan desain ADDIE (Analyze, Design, Develop, Implement, dan Evaluate). Tahap (1) Analisis, dilakukan pada dengan menganalisis permasalah yang ada dalam kehidupan sehari-hari, yakni mahalnya harga kedelai yang merupakan bahan baku dalam pembuatan tempe. Sehingga diperlukan bahan baku alternatif untuk mengantikan kedelai yang memiliki kandungan gizi, protein, karbohidrat, dan lemak yang setarah dengan kedelai, yaitu biji nangka. Selanjutmya menganalisis aspek kimia dalam pembuatan tempe dari biji nangka yang dipelajari siswa dalam pembelajaran di sekolah, kemudian 
menganalisis kompetensi inti dan kompetensi dasar Kelas X SMK untuk pembelajaran fermentasi berdasarkan revisi Kurikulum 2013. Peneliti juga melakukan studi literatur praktikum yang sudah ada pada buku-buku SMK dan jurnal-jurnal tentang tempe dari fermentasi biji nangka. Tahap (2), yaitu desain. Pada tahap ini peneliti mendesain praktikum pembuatan tempe dari fermentasi Biji Nangka (Artocarpus Heterophyllus) untuk meningkatkan literasi sains siswa. Selanjutnya peneliti mengoptimasi prosedur praktikum pembuatan tempe dari fermentasi biji nangka untuk memperoleh prosedur terbaik. Tahap (3) Pengembangan, dalam penelitian ini meliputi, penyusun instrumen desain praktikum berbasis STEM untuk meningkatkan literasi sains siswa berupa prosedur percobaan, LKS, RPP, dan lembar observasi keterlaksaan pembelajaran fermentasi, penyusun instrumen pengukuran literasi sains, yaitu soal pretest dan posttest. Kemudian validasi instrument oleh para ahli. Tahap (4) Implementasi, melibatkan 25 orang siswa SMK. Desain penelitian untuk tahap ini menggunakan quasi-eksperimen dengan tipe one group-pretest-postest.

Teknik analisis data untuk validasi instrument dilakukan dengan menggunakan perhitungan nilai CVR (Content Validity Ratio) dengan kriteria penilaian "ya" untuk bobot 1 dan "tidak" hingga 0 (Lawshe, 1975). Analisis peningkatan kemampuan literasi sains dengan menggunakan $\mathrm{N}$-Gain dengan menggunakan rumus Hake (Meltzer, 2002; Archambault, 2008)

\section{HASIL PENELITIAN}

\section{A. Analisis hubungan kurikulum pada materi fermentasi dan aspek STEM}

Analisis kurikulum pada materi fermentasi dilakukan untuk menetapkan dan mendefinisikan syarat-syarat penyusunan desain praktikum fermentasi dari biji nangka berbasis STEM. Setelah dianalisis, kemudian dibuat matrik hubungan materi fermentasi dengan aspek STEM, aspek literasi dan indikator dalam pembelajaran fermentasi yang disajikan pada Tabel 1.

Tabel 1. Hubungan KD, IPK dan Konsep Fermentasi dan Aspek STEM.

\begin{tabular}{|c|c|c|}
\hline tensi Dasar & IPK & $\begin{array}{c}\text { Konsep Fermentasi dan Aspek } \\
\text { STEM }\end{array}$ \\
\hline $\begin{array}{l}\text { rta kondisi } \\
\text { m } \\
\text { buhan mikroba } \\
\text { roses } \\
\text { atan makanan/ } \\
\text { an/ bahan } \\
\text { pengolahan }\end{array}$ & $\begin{array}{l}\text { askan jenis bahan baku } \\
\text { edia untuk pembuatan } \\
\text { makanan/ minuman/ } \\
\text { industri } \\
\text { askan jenis mikroba yang } \\
\text { kan untuk proses } \\
\text { tasi dalam pembuatan } \\
\text { makanan/minuman/ } \\
\text { ahan industri }\end{array}$ & $\begin{array}{l}\text { 1. Produk makanan minuman } \\
\text { fermentasi } \\
\text { (S, T \& E) } \\
\text { 2. Jenis-jenis mikroba pada } \\
\text { produk makanan minuman } \\
\text { fermentasi } \\
\text { (S \& T) } \\
\text { 3. Faktor-faktor } \\
\text { mempengaruhi pertumbuhan }\end{array}$ \\
\hline $\begin{array}{l}\text { 4.6 Melaksanakan } \\
\text { pembuatan makanan } \\
\text { minuman/ bahan } \\
\text { bakar/ pengolahan } \\
\text { limbah dengan } \\
\text { memanfaatkan } \\
\text { mikroba. }\end{array}$ & $\begin{array}{l}\text { 3.6.3. Menjelaskan kondisi optimum } \\
\text { proses fermentasi } \\
\text { 4.6.1. Melaksanakan pembuatan } \\
\text { produk makanan minuman } \\
\text { dengan pengendalian proses } \\
\text { fermentasi } \\
\text { 4.6.2. } \begin{array}{l}\text { Melakukan pengecekan kualitas } \\
\text { produk }\end{array}\end{array}$ & $\begin{array}{l}\text { mikroba pada proses } \\
\text { fermentasi }(\mathbf{S}) \\
\text { 4. Praktikum pembuatan produk } \\
\text { makanan / minuman } \\
\text { fermentasi } \backslash(\mathbf{S}, \mathbf{T}, \mathbf{E}, \mathbf{M})\end{array}$ \\
\hline
\end{tabular}

Berdasarkan analisis kurikulum pada Tabel 1, peneliti kemudian membuat analisis hubungan aspek STEM, aspek literasi dan indikator dalam pembelajaran fermentasi yang kemudian divalidasi oleh ahli. Analisis hubungan hubungan aspek STEM, aspek literasi dan indikator dalam pembelajaran fermentasi disajikan pada Tabel 2. 
Tabel 2. Hasil Validasi Matrik Hubungan Aspek STEM, Aspek Literasi Dan Indikator Dalam Pembelajaran Fermentasi

\begin{tabular}{|c|c|c|}
\hline Aspek & Literasi Sains & Indikator dalam Pembelajaran Fermentasi \\
\hline \multirow[t]{3}{*}{ Sains } & \multirow[t]{2}{*}{$\begin{array}{l}\text { Menjelaskan } \\
\text { fenomena Ilmiah }\end{array}$} & $\begin{array}{l}\text { Mengidentifikasin bahan baku yang digunakan dalam } \\
\text { pembuatan makanan dan minuman fermentasi }\end{array}$ \\
\hline & & $\begin{array}{l}\text { Menentukan mikroba yang tepat dalam pembuatan } \\
\text { makanan dan minuman fermentasi } \\
\text { Menjelasakan faktor-faktor yang mempengaruhi proses } \\
\text { fermentasi } \\
\text { Menjelaskan pengaruh suhu terhadap fermentasi } \\
\text { Mengidentifikasin bahan baku alternatif yang dapat } \\
\text { digunakan dalam pembuatan tempe dari fermentasi bij } \\
\text { nangka } \\
\text { Menentukan mikroba yang tepat dalam pembuatan } \\
\text { tempe dari fermentasi biji nangka } \\
\text { Membuat reaksi fermentasi tempe dari fermentasi } \\
\text { tempe }\end{array}$ \\
\hline & $\begin{array}{l}\text { Menafsirkan data } \\
\text { dan bukti ilmiah } \\
\text { Mengevaluasi dan } \\
\text { merancang } \\
\text { penelitian ilmiah }\end{array}$ & $\begin{array}{l}\text { Mengemukan argument yang didasarkan pada bukti } \\
\text { adanya benang-benang putih pada permukaan tempe } \\
\text { Menjelaskan cara membuat tempe dari hasil berbagai } \\
\text { sumber yang relevan }\end{array}$ \\
\hline $\begin{array}{l}\text { Teknologi dan } \\
\text { Rekayasa }\end{array}$ & $\begin{array}{l}\text { Mengembangkan } \\
\text { solusi dalam } \\
\text { mencapai tujuan }\end{array}$ & $\begin{array}{l}\text { Menjelaskan tujuan perlakuan yang diberikan selama } \\
\text { proses pembuatan tempe dari fermentasi biji nangka } \\
\text { Menjelaskan fungsi ragi dalam proses fermentasi } \\
\text { tempe } \\
\text { Menggunakan alat dan bahan yang tepat untuk } \\
\text { membuat tempe dari hasil fermentasi } \\
\text { Menggunakan alat dan bahan yang tepat untuk } \\
\text { membuat tempe dari hasil fermentasi }\end{array}$ \\
\hline \multirow[t]{2}{*}{ Matematika } & \multirow{2}{*}{$\begin{array}{l}\text { Menggunakan } \\
\text { konsep, fakta, } \\
\text { prosedur dan } \\
\text { penalaran }\end{array}$} & $\begin{array}{l}\text { Menghitung perbandingan biji nangka dan ragi yang } \\
\text { tepat dalam pembuatan tempe }\end{array}$ \\
\hline & & $\begin{array}{l}\text { Mengambarkan grafik hubungan waktu fermentasi } \\
\text { dengan produk tempe yang di hasilkan }\end{array}$ \\
\hline
\end{tabular}

Berdasarkan hasil validasi hubungan materi fermentasi dengan aspek STEM, aspek literasi dan indikator dalam pembelajaran fermentasi dinyatakan valid dengn nilai CVR 1. Hal ini berarti aspek STEM, literasi dan indikatornya layak dan dapat diterapkan di dalam pembelajaran fermentasi.

B. Hasil validasi LKS pembelajaran fermentasi dengan menggunakan praktikum berbasis STEM untuk meningkatkan literasi sains

Prosedur praktikum fermentasi tempe dari biji nangka yang diperoleh dari hasil optimasi kemudian disusun dalam format LKS. Selanjutnya divalidasi oleh validator yang terdiri dari 4 orang dosen dan 2 guru. Hasil validasi disajikan pada Tabel 3. Tujuan validasi instrumen format desain praktikum dalam bentuk LKS adalah untuk mengetahui kevaliditan keseluruhan desain panduan praktikum yang dikembangkan. Instrumen yang valid berarti alat ukur yang digunakan untuk mendapatkan data itu valid. 
Tabel 3. Hasil Validasi LKS

\begin{tabular}{llcl}
\hline No $\quad$ Indikator Penilaian & Rata-rata CVR & Kriteria \\
\hline 1 Komponen isi & 1 & Valid \\
2 Komponen penyajian & 1 & Valid \\
3 & Komponen kegrafisan & 1 & Valid \\
4 Bahasa & 1 & Valid \\
\hline
\end{tabular}

Tabel 3, menunjukkan bahwa dari segi komponen isi, kegiatan dalam LKS telah valid mengintegrasikan sains, teknologi, rekayasa dan matematika untuk meningkatkan literasi sains siswa. Fenomena-fenomena ilmiah dan produk-produk yang disajikan sesuai dengan konsep fermentasi, yang mengarahkan siswa untuk menemukan konsep fermentasi yang sedang dipelajari. Setiap kegiatan yang disajikan pada prosedur pembuatan tempe dari biji nangka dapat meningkatkan kemampuan STEM dan literasi siswa, khususnya pada aspek teknologi dan rekayasa. Penggunaan alat dan bahan dapat meningkatan kemampuan teknologi dan rekayasa siswa. Pertanyaan pada tugas mengarahkan siswa untuk memahami materi yang sedang diperlajari. Interpretasi data-data hasil praktikum dapat meningkatkan kemampuan matematika siswa. Dari komponen penyajian, tujuan pembelajaran telah dijelaskan pada setiap kegiatan, serta sesuai dengan kompetensi dasar dan indikator pembelajaran. Urutan kegiatan disajikan secara sistematis serta menyediakan ruang yang cukup untuk siswa menulis jawaban. Gambar-gambar yang digunakan juga telah sesuai dengan fenomana ilmiah (permasalahan) yang disajikan. LKS yang disajikan juga menarik dan meningkatkan minat baca siswa. Penggunaan LKS dengan pendekatanSTEM efektif dalam melatih keterampilan berpikir kreatif siswa (Aldila dkk., 2017). Dari komponen kegrafisan,tulisan, tabel dan gambar memiliki ukuran yang proposional, warna yang tajam, serta keterangan tabel yang jelas Dari komponen bahasa, bahasa yang digunakan baku, menarik, dan mudah untuk dipahami, serta tidak menimbulkan makna ganda.

C. Keterlaksanaan praktikum berbasis STEM pada pembelajaran fermentasi melalui pembuatan tempe dari biji nangka

Keterlaksanaan pembelajaran diamati oleh 3 observer selama kegiatan pembelajaran berlangsung. Pengamatan dilakukan untuk melihat kesesuaian antara tahapan pembelajaran yang terdapat dalam RPP dengan fakta yang terjadi selama pelaksanaan proses pembelajaran. Setelah pembelajaran selesai, dilaksanakan postest untuk mengetahui peningkatan literasi siswa setelah praktikum berbasis STEM diterapkan. Perhitungan rata-rata keterlaksanaan masing-masing langkah pembelajaran praktikum berbasi STEM dalam pembelajaran fermentasi melalui pembuatan tempe dari fermentasi biji nangka pada kegiatan siswa dilihat pada Tabel 4. Setelah pembelajaran selesai, dilaksanakan postest untuk mengetahui peningkatan literasi siswa setelah praktikum berbasis STEM diterapkan

Tabel 4. Rata-rata keterlaksanaan masing-masing langkah pembelajar pada Pertemuan I

\begin{tabular}{llcc}
\hline \multicolumn{1}{c}{ Langkah-langkah PBL } & Aspek STEM & \% Keterlaksaan \\
\hline Fase 1: & Orientasi pada masalah & Teknologi dan & 100 \\
Fase 2: & Pengorganisasian siswa & Engineering & 100 \\
Fase 3: & Penyelidikan individu dan kelompok & Sains dan & 100 \\
Fase 4: & Mengembangkan dan menyajikan laporan & Teknologi & 72,5 \\
Fase 5: & Menganalisis dan mengevaluasi proses pemecahan & 83 & \\
& masalah & &
\end{tabular}

Data pada Tabel 4, menunjukkan bahwa fase yang paling tinggi dalam pembelajaran adalah Fase 1, 2 dan 3 dengan presentasi keterlaksaan 100\% yang berarti keterlaksaan pembelajaran pada ketiga fase sangat baik. Hal ini menunjukkan bahwa siswa mampu untuk membuat pertanyaan yang berkaitan dengan produk-produk makanan dan minuman fermentasi. Selain itu 
siswa membentuk kelompok dengan tertib kemudian berdiskusi untuk menentukan nama, bahan utama, jenis mikroorganisme yang digunakan untuk membuat produk makanan dan minuman tersebut serta menjawab pertanyaan soal diskusi dengan sangat baik. Hal ini berarti siswa mampu untuk berkolaborasi dengan sangat baik dalam menjawab pertanyaan-pertanyaan yang ada di dalam LKS.

Sedangkan fase yang paling rendah, yaitu Fase 4 mengembangkan dan menyajikan laporan sebesar $72,5 \%$. Hal ini dikarenakan pada tahap tabulasi data hasil diskusi kelompok, siswa keliru dalam menulis nama mikroba yang sesuai dengan aturan penulisan Binominal Nomenclature. Selain itu rendahnya Fase 4 ini juga menunjukkan bahwa siswa belum dapat mengkomunikasikan data hasil diskusikan kelompok dengan baik. Oleh karena pada tahap ini perlu bimbingan dan penjelasan guru untuk tata cara penulisan Binominal Nomenclature yang baik dan benar, sehingga siswa mampu untuk mengkomunikasikan hasil diskusi kelompok mereka dengan sangat baik.

Pada pertemuan ini aspek STEM yang diterapkan adalah aspek sains dan teknologi. Aspek teknologi $(100 \%)$ pada pertemuan pertama lebih tinggi daripada aspek sains $(71,43)$. Hal ini berarti dalam pembelajaran siswa dapat memanfaatkan teknologi dengan tepat untuk menunjang kualitas pembelajaran. Hasil ini sejalan dengan hasil penelitian Sumintono (2010), yang menyatakan bahwa dengan teknologi internet siswa dapat memperoleh informasi-informasi yang menambah pengetahuan mereka. Sedangkan rendahnya aspek sains dalam pembelajaran Pertemuan I ini karena kurangnya konsep sains siswa tentang penulisan nama Binominal Nomenclature untuk mikroba. Adanya teknologi dalam bidang industri banyak produk dan makanan dihasilkan sehingga dapat menunjang kualitas hidup masyarakat. Aspek sains dan teknolgi dalam kehidupan sehari-hari tidak dapat dipisahkan satu sama lain. Aspek sain melandasi perkembangan teknologi, sedangkan teknologi menunjang perkembangan sains, sains terutama digunakan untuk aktivitas discovery dalam upaya memperoleh penjelasan tentang objek dan fenomena alam, namun juga untuk aktivitas penemuan, misalnya dalam penemuan rumus-rumus. Teknologi merupakan aplikasi sains yang terutama untuk kegiatan invention, berupa alat-alat atau barang-barang untuk memenuhi kebutuhan masyarakat (Reynolds dkk., 2013).

Pada pertemuan II, dilaksanakan praktikum pembuatan tempe dari fermentasi biji nangka. Pelaksaan praktikum pada pertemuan ini menggunakan model pembelajaran Project Based Learning (PjBL). Keterlaksaan praktikum pada pertemuan II adalah 93,89\% dari kegiatan guru dan $93,36 \%$ dari kegiatan siswa. Artinya seluruh kegiatan praktikum tempe dari fermentasi biji nangka dalam pembelajaran fermentasi Pertemuan II terlaksanakan dengat sangat baik. Hal ini berarti perencanaan pembelajaran berjalan sesuai rencana (RPP). Perhitungan rata-rata keterlaksanaan pertemuan II disajikan pada Gambar 1.

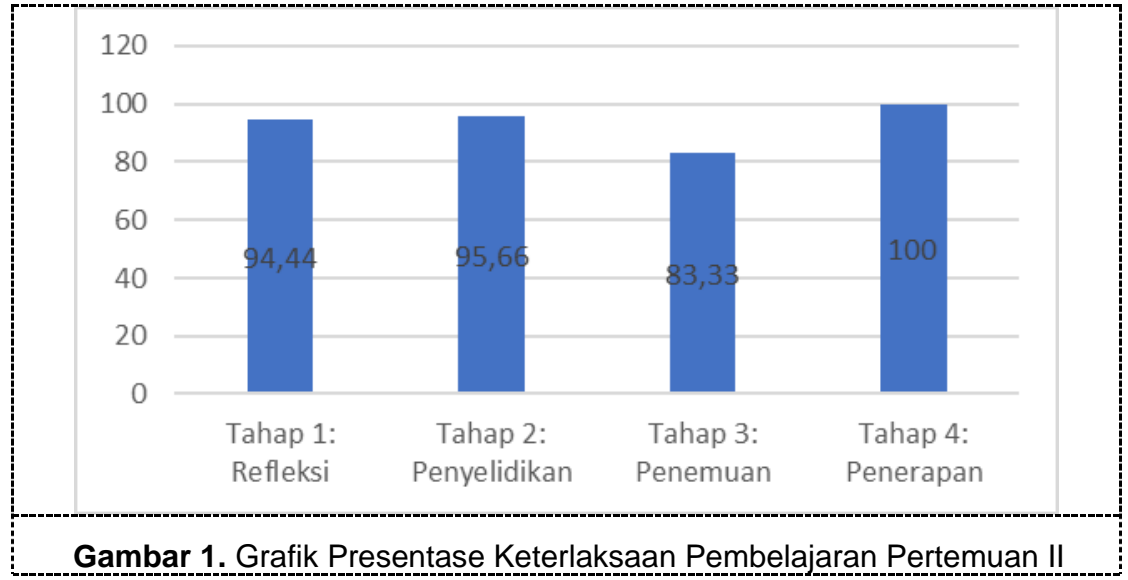

Data di atas menunjukan bahwa kegiatan yang memiliki presentasi keterlaksaan paling rendah adalah penemuan, yakni 83,33 . Hal ini dikarenakan timbangan yang digunakan untuk 
menimbang ragi hanya 1 , sehingga diperlukan waktu yang lebih lama untuk menimbang ragi dan melebihi alokasi waktu yang ditentukan. Sedangkan kegiatan yang memiliki presentasi keterlaksaan tertinggi adalah application yakni 100\%. Hal ini berarti kelompok mampu untuk melaksanakan proyek pembuatan tempe dari fermentasi biji nangka dengan sangat baik. Pertemuan ini menggunakan model PjBL karena proses fermentasi membutuhkan waktu 2x24 jam sehingga digunakan model PJBL dengan produk berupa Tempe dari biji nangka. Selain itu hasil penelitian Chanlin (2008), Hulobova (2008), Akgun (2013) yang menunjukan bahwa penggunaan model pembelajaran PjBL diharapkan menyelesaikan masalah yang diberikan dan lebih menekankan pada produk yang dihasilkan. Produk yang dihasilkan dari penggunaan PjBL dalam pembelajaran sains dapat menjadi kontribusi siswa terhadap peningkatan kualitas kehidupan. Penyelesaian masalah dalam kehidupan dan pembuatan produknya dapat dikerjakan secara individu maupun kelompok. Pengerjaan secara berkelompok dapat mendorong mahasiswa untuk bekerja sama namun tetap bertanggung jawab atas pekerjaannya secara mandiri. Selain itu, secara berkelompok siswa dapat melakukan pengolaan pembelajaran secara mandiri yang cocok dengan keadaan kelompok masing-masing.

Pada petemuan III siswa mempresentasikan proyek mereka. Tahap PjBL pada pertemuan ini adalah komunikasi. Semua kelompok membawah produk tempe mereka beserta laporan dan video pembuatan tempe dari fermentasi biji nangka, kemudian dipresentasikan di depan kelas. Keterampilan berkomunikasih siswa dilatih saat mereka mempresentasikan laporan proyek mereka, serta pada saat guru dan kelompok lain bertanya terkait produk yang dibuat mereka. Selain itu kemampuan mereka dalam menulis laporan juga dapat terlihat pada saat mereka membuat tabel dan grafik. Keterlaksaan praktikum berbasi STEM dalam pembelajaran fermentasi melalui pembuatan tempe dari fermentasi biji nankga adalah $100 \%$ dari kegiatan guru dan $92,06 \%$ dari kegiatan siswa. Artinya presentasi produk tempe dari fermentasi biji nangka dalam kriteria seluruh kegiatan terlaksana dengan sangat baik. Hal ini berarti perencanaan pembelajaran berjalan sesuai rencana (RPP). Berikut disajikan hasil penilaian kerja kelompok pembuatan tempe dari fermentasi biji nangka pada Tabel 5.

Tabel 5. Hasil Penilaian Kerja Kelompok Pembuatan Tempe dariFermentasi Biji Nangka

\begin{tabular}{clc}
\hline No & \multicolumn{1}{c}{ Aktifitas Yang Dinilai } & \% Keterlaksaan \\
\hline 1 & Membuat perkiraan & 87 \\
2 & Membuat kesimpulan & 87 \\
3 & Memilih alat yang tepat untuk mencapai tujuan dan & 100 \\
& menuliskan kegunaannya & \\
4 & Menimbang ragi & 100 \\
5 & Keterampilan membuat video pembuatan proyek & 100 \\
6 & Pengumpulan data & 87 \\
7 & Menginterpretasikan data dalam bentuk tabel & 87 \\
8 & Menjawab Pertanyaan Tugas & 87 \\
9 & Mensintesis data menjadi sebuah kesimpulan & 73 \\
10 & Pembagian tugas dalam kelompok & 100 \\
\hline
\end{tabular}

Data pada Tabel 5, menunjukkan bahwa aktivitas kelompok yang paling tinggi ada pada aktivitas siswa dalam memilih alat yang tepat untuk mencapai tujuan, menimbang ragi, serta membuat video pembuatan proyek. Hal ini berarti kelompok mampu untuk memilih alat untuk percobaan dengan tepat. Adanya prosedur percobaan dalam LKS juga membantu siswa dalam dapat menentukan dengan tepat alat yang mereka perlukan untuk melaksanakan proyek mereka. Selain itu siswa juga mampu menimbang ragi dengan tepat, hal ini menunjukan bahwa mereka sudah sering dilatih dalam menimbang suatu bahan, sehingga mereka mampu untuk menimbang ragi dengan tepat dan konsisten. Selanjutnya dengan berbantu teknologi siswa mampu untuk mendokumentasikan proyek mereka dalam video dengan kualitas yang baik. 


\section{E. Peningkatan Literasi Sains}

Peneliti melakukan analisis terhadap hasil pretest dan postest 25 siswa, untuk mengetahui peningkatan literasi sains siswa setelah praktikum fermentasi tempe dari biji nangka di terapkan. Data prestest dan postest siswa kemudian di uji normalitasnya. Hasil uji normalitas untuk data pretest dan postest disajikan pada Tabel 6 .

Tabel 6. Hasil uji normalitas untuk data Pretest dan Postest

\begin{tabular}{ccc}
\hline \multirow{2}{*}{ Data } & Pretest & Postest \\
\cline { 2 - 3 } & Uji Normalitas & Uji Normalitas \\
\hline $\mathrm{N}$ & 25 & 25 \\
$\mathrm{~A}$ & 0,05 & 0,05 \\
Sig. & .069 & .217 \\
Keputusan & $\mathrm{H}_{0}$ diterima & $\mathrm{H}_{0}$ diterima \\
Kesimpulan & \multicolumn{2}{c}{ Data berdistribusi Normal } \\
\hline
\end{tabular}
homogen.

Data uji normalitas pada Tabel 6 , menunjukkan bahwa semua data berdistribusi normal dan

Selanjutnya dilakukan perhitungan uji $\mathrm{N}$-Gain untuk mengetahui peningkatan literasi sains siswa (Meltzer, 2002; Archambault, 2008). Hasil perhitungan uji N-Gain, menunjukan bahwa ratarata $\mathrm{N}$-Gain score adalah sebesar 0,76 termasuk dalam katagori efektif. Dengan demikian dapat disimpulkan bahwa penggunaan desain praktikum tempe dari fermentasi biji nangka pada pembelajaran fermentasi efektif untuk meningkatan literasi sains siswa SMK dengan skor $\mathrm{N}$-Gain minimal 0,58 dan $N$-Gain maksimal 0,93. Selanjutnya peneliti menganalisis data pretest dan postest dari setiap indikator literasi sains. Hasil analis rata-rata pretest, postest, $\mathrm{N}$-Gain data dari masingmasing indikator literasi sains disajikan pada Tabel 7.

Tabel 7. Rata-rata pretest, postest, $N$-Gain data dari masing-masing indikator literasi sains

\begin{tabular}{|c|c|c|c|c|}
\hline No & Literasi Sains & Pretest & Postest & $N$-Gain \\
\hline 1 & Menjelaskan fenomena ilmiah & 21 & 81 & 0,76 \\
\hline 2 & Menafsirkan data dan bukti ilmiah & 8 & 92 & 0,91 \\
\hline 3 & $\begin{array}{l}\text { Mengevaluasi dan merancang } \\
\text { penelitian ilmiah }\end{array}$ & 24 & 84 & 0,79 \\
\hline 4 & $\begin{array}{l}\text { Mengembangkan solusi dalam } \\
\text { mencapai tujuan }\end{array}$ & 20 & 83 & 0,79 \\
\hline 5 & $\begin{array}{l}\text { Menggunakan konsep, fakta, } \\
\text { prosedur, dan penalaran }\end{array}$ & 18 & 76 & 0,71 \\
\hline
\end{tabular}

Data pada Tabel 7, menunjukkan bahwa indikator literasi sains yang mengalami peningkatan paling tinggi adalah menafsirkan data dan bukti ilmiah. Hal ini berarti setelah praktikum berbasis STEM diterapkan dalam pembelajaran fermentasi, siswa mampu meningkatkan kemampuan mereka dalam menafsirkan data dan bukti ilmiah. Hal ini sejalan dengan pendapat Rustaman (2011) yang menyatakan bahwa, dengan melakukan praktikum siswa akan menjadi lebih yakin atas satu hal dari pada hanya menerima dari guru dan buku, serta dapat memperkaya pengalaman siswa dalam menafsirkan data dan bukti ilmiah, serta mengembangkan sikap ilmiah, dan hasil belajar akan bertahan lebih lama dalam ingatan siswa. Sedangkan indikator literasi sains yang paling rendah adalah menggunakan konsep, fakta, prosedur, dan penalaran. Sebagian siswa belum dapat menjawab pertanyaan terkait penentuan grafik yang mengambarkan konsep fermentasi. Hal ini berarti kemampuan siswa menggunakan model, diagram dan simbol-simbol untuk merepresentasikan suatu konsep serta kemampuan mengubah suatu bentuk representasi ke bentuk lainnya masih rendah. Hal ini sejalan dengan hasil penelitian Legi (2008) dan Suryowati 
(2015), yang menyatakan bahwa siswa dengan kemampuan rendah akan sulit untuk menciptakan dan menggunakan representasi gambar maupun simbolik. Dua penelitian tersebut (Legi, 2008; Suryowati, 2015) kemudian menyarankan penggunaan pendekatan pembelajaran dengan mengajukan masalah yang sesuai dengan pengalaman dan tingkat pengetahuan siswa untuk mengembangkan kemampuan representasi matematis. Selain itu diperlukan banyak latihan soal terkait penggunaan diagram atau simbol-simbol untuk mempresentasikan suatu konsep guna meningkatkan kemampuan literasi matematika siswa.

\section{KESIMPULAN}

Berdasarkan hasil penelitian yang telah dilakukan maka, diperoleh simpulan tentang desain praktikum pembuatan tempe dari fermentasi biji nangka antara lain sebagai berikut:

1. Karakteristik desain praktikum berbasis STEM antara lain: (a) Memecahkan permasalah yang ada dalam kehidupan sehari-hari. (b) Mengintegrasikan STEM di dalam kegiatan praktikum. (c) Praktikum berbasis proyek. (d) Meningkatan kemampuan 4C siswa, yakni meningkatkan kemampuan siswa dalam berkolaborasi dalam memecahkan masalah, meningkatkan kemampuan siswa dalam mengkomunikasikan data yang mereka peroleh dari percobaan dalam bentuk tabel dan grafik, meningkatkan kemampuan siswa dalam berfikir kritis dan kreatif dalam memecahkan permasalah. (e) Selain itu desain praktikum juga memperkaya kegiatan praktikum pada pembelajaran yang diberikan kepada siswa SMK Kelas $X$ yang bertujuan untuk meningkatan literasi sains siswa.

2. Keseluruhan pembelajaran fermentasi dengan praktikum berbasis STEM dapat terlaksanakan dengan sangat baik. Hasil analisis data dan pretest siswa setelah pembelajaran terlaksanakan menunjukan bahwa indikator literasi sains siswa yang mengalami peningkatan yang paling tinggi adalah menafsirkan data dan bukti ilmiah, yakni nilai $N$-Gain sebesar 0,91. Hal ini berarti setelah praktikum berbasis STEM diterapkan dalam pembelajaran fermentasi, siswa mampu meningkatkan kemampuan mereka dalam menafsirkan data dan bukti ilmiah. Sedangkan indikator literasi sains yang paling rendah adalah menggunakan konsep, fakta, prosedur, dan penalaran, yakni nilai $N$-Gain sebesar 0,71 . Sebagian siswa belum dapat menjawab pertanyaan terkait penentuan grafik yang mengambarkan konsep fermentasi. Hal ini berarti kemampuan siswa menggunakan model, diagram dan simbol-simbol untuk merepresentasikan suatu konsep serta kemampuan mengubah suatu bentuk representasi ke bentuk lainnya masih rendah.

\section{DAFTAR PUSTAKA}

Afriana, J., Permanasari, A., \& Fitriani, A. (2016). Penerapan project based learning terintegrasi STEM untuk meningkatkan literasi sains siswa ditinjau dari gender. Jurnal Inovasi Pendidikan IPA, 2(2), 202-212.

Akgun, O. E. (2013). Technology in STEM project-based learning. In STEM Project-Based Learning (pp. 65-75). Brill Sense.

Aldila, C., Abdurrahman, A., \& Sesunan, F. (2017). Pengembangan LKPD Berbasis STEM untuk Menumbuhkan Keterampilan Berpikir Kreatif Siswa. Jurnal Pembelajaran Fisika, 5(4).

Archambault, J., Burch, T., Crofton, M., \& McClure, A. (2008). The effect of developing kinematics concepts graphically prior to introducing algebraic problem solving techniques. Action Research required for the Master of Natural Science degree with concentration in physics.

Bagasta, A. R., Rahmawati, D., Wahyuni, I. P., \& Prayitno, B. A. (2018). Profil Kemampuan Literasi Sains Peserta Didik di Salah Satu SMA Negeri Kota Sragen. PEDAGOGIA: Jurnal Pendidikan, 7(2), 121-129.

Balka, D. (2011). Standards of mathematical practice and STEM. Math-science connector newsletter, 6-8. 
Bybee, R. W. (2013). The case for STEM education: Challenges and opportunities. NSTA press.

Capraro, M. M., \& Jones, M. (2013). Interdisciplinary STEM project-based learning. In STEM project-based learning. Brill Sense.

ChanLin, L. J. (2008). Technology integration applied to project-based learning in science. Innovations in education and teaching international, 45(1), 55-65.

Firman, H. (2018). Penerapan Pembelajaran Berbasis STEM Untuk Materi Penanggulangan Limbah Polimer. Disajikan dalam Seminar Nasional Peran Penelitian dan Pendidikan Kimia dalam Penanggulangan Limbah Polimer

Firman, H. (2018). Mewujudkan Pendidikan Kimia di Era Industri 4.0: Pembelajaran Berbasis Stem Sebagai Alternatif. Disajikan dalamSeminar Nasional Pendidikan Kimia dalam Tantangan Revolusi Industri 4.0

Greenstein, L. M. (2012). Assessing 21st century skills: A guide to evaluating mastery and authentic learning. Corwin Press.

Hayati, S. (2009). Pengaruh Waktu Fermentasi Terhadap Kualitas Tempe Dari Biji Nangka (Artocarpus Heterophyllus) dan Penentuan Kadar Zat Gizinya.

Hofstein, A., Shore, R., \& Kipnis, M. (2004). Providing high school chemistry students with opportunities to develop learning skills in an inquiry-type laboratory: A case study. International Journal of Science Education, 26(1), 47-62.

Holbrook, J., \& Rannikmae, M. (2009). The meaning of scientific literacy. International Journal of Environmental and Science Education, 4(3), 275-288.

Holubova, R. (2008). Effective Teaching Methods--Project-based Learning in Physics. Online Submission, 5(12), 27-36.

Ismail, I., Permanasari, A., \& Setiawan, W. (2016). Efektivitas virtual lab berbasis STEM dalam meningkatkan literasi sains siswa dengan perbedaan gender. Jurnal Inovasi Pendidikan IPA, 2(2), 190-201.

Khaeroningtyas, N., Permanasari, A., \& Hamidah, I. (2016). Stem learning in material of temperature and its change to improve scientific literacy of junior high school. Jurnal Pendidikan IPA Indonesia, 5(1), 94-100.

Lawshe, C. H. (1975). A quantitative approach to content validity. Personnel psychology, 28(4), 563-575.

Legi, Y. M. (2009). Kemampuan Representasi Matematis Siswa Kelas IV SD Melalui Pendidikan Matematika Realistik pada Konsep Pecahan Dan Konsep Pecahan Senilai. DISERTASI dan TESIS Program Pascasarjana UM.

Lou, S. J., Liu, Y. H., Shih, R. C., \& Tseng, K. H. (2011). The senior high school students' learning behavioral model of STEM in PBL. International Journal of Technology and Design Education, 21(2), 161-183.

Meltzer, D. E. (2002). The relationship between mathematics preparation and conceptual learning gains in physics: A possible "hidden variable" in diagnostic pretest scores. American journal of physics, $70(12), 1259-1268$.

Nofiana, M., \& Julianto, T. (2018). Upaya Peningkatan Literasi Sains Siswa Melalui Pembelajaran Berbasis Keunggulan Lokal. Biosfer: Jurnal Tadris Biologi, 9(1), 24-35.

Permanasari, A. (2016, October). STEM education: Inovasi dalam pembelajaran sains. In Seminar Nasional Pendidikan Sains VI 2016. Sebelas Maret University.

Reynolds, D., Yazdani, N., \& Manzur, T. (2013). STEM high school teaching enhancement through collaborative engineering research on extreme winds. Journal of STEM Education: Innovations and Research, 14(1).

Roberts, A. (2012). A justification for STEM education. Technology and engineering teacher, May/June 2012.

Roberts, A. (2012). A justification for STEM education. Technology and engineering teacher, 71(8), $1-4$.

Rustaman, N. (2011). Materi dan pembelajaran IPA SD. Jakarta: Universitas Terbuka. 
Sumintono, M. B., Ibrahim, M. A., \& Phang, F. A. (2010). Pengajaran sains dengan praktikum laboratorium: Perspektif dari guru-guru sains SMPN di kota Cimahi. Jurnal Pengajaran MIPA, 15(2), 120-127.

Suryowati, E. (2015). Kesalahan siswa sekolah dasar dalam merepresentasikan pecahan pada garis bilangan. AKSIOMA: Jurnal Program Studi Pendidikan Matematika, 4(1).

Windyariani, S. (2017). Kemampuan literasi sains siswa sd pada konteks melestarikan capung. Biosfer: Jurnal Pendidikan Biologi, 10(1), 17-21. 